\title{
Results of a 6-month intensive outpatient management programme for patients with chronic heart failure - a pilot study
}

\section{Denis Došen*, Dubravko Došen', Dejan Došen², Dora Fabijanovićc Maja Čikeš², Davor Miličić ${ }^{2}$}

'Private Cardiovascular Clinic "Dr. Došen", Karlovac, Croatia

${ }^{2}$ University of Zagreb School of Medicine, University Hospital Centre Zagreb, Zagreb, Croatia
RECEIVED:

September 24, 2017

ACCEPTED:

September 26, 2017

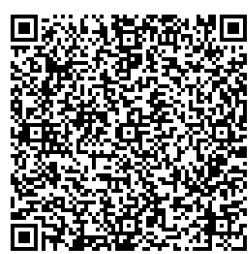

KEYWORDS: outpatient heart failure clinic, advanced heart failure, drug therapy optimization. CITATION: Cardiol Croat. 2017;12(9-10):351-352. I https://doi.org/10.15836/ccar2017.351

*ADDRESS FOR CORRESPONDENCE: Denis Došen, Poliklinika dr. Došen, Trg Petra Zrinskog 7, HR-47000 Karlovac, Croatia. / Phone: +385-98-548-540 / E-mail: denisdosen@gmail.com

ORCID: Denis Došen, http://orcid.org/0000-0003-3490-5505 • Dubravko Došen, http://orcid.org/0000-0002-0263-2920 Dejan Došen, http://orcid.org/0000-0002-2641-4768 • Dora Fabijanović, http://orcid.org/0000-0003-2633-3439

Maja Čikeš, http://orcid.org/0000-0002-4772-5549 • Davor Miličić, http://orcid.org/0000-0001-9101-1570

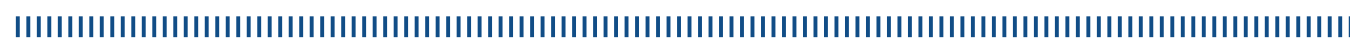

Introduction: Heart failure (HF) has been singled out as a staggering clinical and public health problem, associated with significant mortality, morbidity, and healthcare expenditures. Heart failure patients often experience a loss of productivity and quality of life. ${ }^{1}$ This pilot study evaluated the effectiveness of a multidisciplinary, outpatient HF clinic during 6 months period. Our goal was to determine whether an intensive intervention at a HF clinic improves patient's functional status (New York Heart Association (NYHA) class), echocardiographic parameters, and levels of NT-proBNP. Patients with optimal drug therapy at the start and at the end of the study were also evaluated.

Patients and Methods: Our follow-up consisted of 8 scheduled patient contacts - initial visit at day 1 , telephone contact at day 3, and visits to the clinic at weeks 1, 3, 5, 7 and at months 3 and 6 . Verbal and written comprehensive education, optimization of treatment, easy access to the clinic, and advice for symptom monitoring and self-care were provided. Echocardiography study, six-minute walk test (6MWT) and levels of NT-proBNP were performed on an initial and the last visit. For group comparison Pearson chi-square, Fischer's Exact test, Wilcoxon Signed Ranks Test and Paired Samples T-Test were used.

Results: A total of 35 HF pts (mean age $76 \pm 6$ years, $40 \%$ male) with various comorbidities (atrial fibrillation (57\%), diabetes mellitus (32\%), arterial hypertension (74\%), chronic obstructive pulmonary disease $(6 \%)$ diagnosed per the current guidelines were prospectively assessed in the period of 6 months. In follow-up period significant reduction of body mass index, average heart rate and systolic blood pressure was observed (Table 1). Echocardiography study showed improvements in systolic pulmonary pressure and left ventricular ejection fraction (Table 2).

Conclusion: A HF outpatient clinic involving an intensive intervention by a clinician, substan-
TABLE 1. Patients characteristics.

\begin{tabular}{lccc} 
Segment & Visit 1 & $\begin{array}{c}\text { Visit 6 } \\
\text { months }\end{array}$ & P-value \\
\hline BMI (mean \pm SD) & $31.42 \pm 5.45$ & $30.70 \pm 4.87$ & 0.02 \\
\hline SBP (mean \pm SD) & $127 \pm 22$ & $119 \pm 9$ & 0.02 \\
\hline HR (mean \pm SD) & $76 \pm 21$ & $69 \pm 11$ & 0.03 \\
\hline 6MWT (median, IQR) & $200(82-280)$ & $270(170-325)$ & $<0.01$ \\
\hline NT-proBNP (median, IQR) & $1873(929-3301)$ & $1676(434-4032)$ & 0.183 \\
\hline NYHA (\%) & $20(59)$ & $32(97)$ & $<0.01$ \\
II & $14(41)$ & $1(3)$ & \\
III & $32(94)$ & $31(92)$ & 0.52 \\
\hline OMT & $21(62)$ & $23(72)$ & 0.30 \\
\hline Beta-blockers (\%) & $8(24)$ & $23(72)$ & $<0.01$ \\
\hline ACEI / ARBs (\%) & $3(9)$ & $5(16)$ & 0.46 \\
\hline MRA (\%) & $33(99)$ & $32(97)$ & 1.0 \\
\hline ARNI (\%) & & & \\
\hline Diuretics (\%) & & & \\
\hline
\end{tabular}

$\mathrm{BMI}=$ body mass index, $\mathrm{SBP}=$ systolic blood pressure, $\mathrm{HR}=$ heart rate, $6 \mathrm{MWT}=6$ Minute Walk Test, NYHA = New York Heart Association, OMT = optimal medical therapy, ACEI = Angiotensin-converting-enzyme inhibitor, ARBs = Angiotensin receptor blockers, MRA = Mineralocorticoid receptor antagonist, ARNI = Angiotensin Receptor-Neprilysin Inhibitors 
tially improves patient's functional status (NYHA class, 6MWT) as well as echocardiographic parameters. We also showed that mineralocorticoid receptor antagonists are still underutilized in the treatment of heart failure in our region and that further improvements in their prescribing are needed.
TABLE 2. Echocardiographic parameters.

\begin{tabular}{lccc} 
Segment & Visit $\mathbf{1}$ & Visit $\mathbf{6}$ months & P-value \\
\hline EDV (mean \pm SD) & $139 \pm 62$ & $131 \pm 54$ & 0.16 \\
\hline LVEF (mean \pm SD) & $43 \pm 14$ & $48 \pm 13$ & $<0.01$ \\
\hline E/E' (mean \pm SD) & $12.3 \pm 4.2$ & $11.7 \pm 4.2$ & 0.34 \\
\hline LAVI (mean \pm SD) & $60.2 \pm 19.7$ & $61.1 \pm 16.1$ & 0.74 \\
\hline TAPSE (mean \pm SD) & $18 \pm 4$ & $20 \pm 4$ & 0.01 \\
\hline SPAP (mean \pm SD) & $52 \pm 15$ & $27 \pm 15$ & 0.01 \\
\hline
\end{tabular}

$E D V=$ End-diastolic volume, $L V E F=$ Left ventricular ejection fraction, $L A V I=$ Left atrial volume index, TAPSE = Tricuspid annular plane systolic excursion, SPAP = Systolic pulmonary artery pressure

1. Ponikowski P, Voors AA, Anker SD, Bueno H, Cleland JG, Coats AJ, et al; Authors/Task Force Members. 2016 ESC Guidelines for the diagnosis and treatment of acute and chronic heart failure: The Task Force for the diagnosis and treatment of acute and chronic heart failure of the European Society of Cardiology (ESC)Developed with the special contribution of the Heart Failure Association (HFA) of the ESC. Eur Heart J. 2016 Jul 14;37(27):2129-200. https://doi.org/10.1093/eurheartj/ehw128 